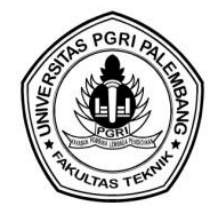

\title{
PENILAIAN RESIKO KESEHATAN LINGKUNGAN (EHRA) DI DESA BATU PUTIH KECAMATAN BATURAJA BARAT KABUPATEN OGAN KOMERING ULU
}

\author{
Eriyana Yulistya $^{1 *}$, Maria Lusia ${ }^{2}$, Enda Kartika Sari ${ }^{3}$ \\ ${ }^{12}$ Prodi Teknik Lingkungan, Fakultas Teknik dan Komputer, Universitas Baturaja \\ ${ }^{3}$ Prodi Teknik Sipil, Fakultas Teknik dan Komputer, Universitas Baturaja \\ "Corresponding Author, Email : ria09081978@gmail.com
}

\begin{abstract}
ABSTRAK
Penilaian Risiko Kesehatan Lingkungan (Environmental Health Risk Assessment / EHRA) adalah sebuah studi partisipatif di Kabupaten/Kota untuk memahami kondisi fasilitas sanitasi dan higinitas serta perilakuperilaku masyarakat pada skala rumah tangga. Berdasarkan data EHRA tahun 2018, Desa Batu Putih Kecamatan Baturaja Barat tergolong desa yang memiiliki risiko sangat tinggi dalam hal kesehatan lingkungan yang memiliki resiko kesehatan lingkungan yang tinggi karena buruknya kondisi sanitasi wilayah tersebut dan berpotensi besar terjadinya kasus kejadian penyakit. Permasalahan dalam penelitian ini adalah kualitas kesehatan lingkungan serta prilaku masyarakat di Desa Batu Putih Kecamatan Baturaja Barat. Tujuan dari penelitian ini adalah untuk mengetahui tentang kualitas kesehatan lingkungan dan perilaku masyarakat di Desa Batu Putih Kecamatan Baturaja Barat Kabupaten Ogan Komering Ulu dengan menggunakan panduan praktis EHRA (Environmental Health Risk Assessment) tahun 2014. Metode pertanyaan dalam kuesioner dan lembar pengamatan dibatasi sesuai dengan lima pilar sanitas total berbasis masyarakat (STBM) dari Kementerian Kesehatan RI, prilaku hidup bersih dan sehat (PHBS) termasuk praktek cuci tangan pakai sabun (CTPS). Dari hasil penelitian didapatkan bahwa sampah rumah tangga tidak dikelola dengan baik, sebagian besar pengelolaan sampah yang dilakukan oleh rumah tangga adalah dengan cara dibakar. Petugas pengangkut sampah tidak pernah melakukan pengambilan sampah ke rumah-rumah penduduk. Sebanyak $73 \%$ responden tidak memiliki jamban pribadi dan $47 \%$ responden tidak memiliki sarana pengelolaan air limbah (SPAL) dan $100 \%$ rersponden melakukan prilaku hieginis dan sanitasi yaitu dengan melakukan cuci tangan pakai sabun.
\end{abstract}

Kata Kunci : Resiko Kesehatan Lingkungan; Sanitasi Lingkungan; Higienitas

\begin{abstract}
The Environmental Health Risk Assessment (EHRA) is a participatory study in a district/city to understand the condition of sanitation and hygiene facilities as well as community behaviors at the household scale. Based on 2018 EHRA data, Batu Putih Village, Baturaja Barat District is classified as a village that has a very high risk in terms of environmental health which has a high environmental health risk due to poor sanitation conditions in the area and has a high potential for disease occurrence. The problem in this study is the quality of environmental health and community behavior in Batu Putih Village, Baturaja Barat District. The purpose of this study was to find out about the quality of environmental health and community behavior in Batu Putih Village, Baturaja Barat District, Ogan Komering Ulu Regency using the 2014 Environmental Health Risk Assessment (EHRA) practical guide. the pillars of community-based total sanitation (STBM) from the Indonesian Ministry of Health, clean and healthy living behavior (PHBS) including the practice of washing hands with soap (CTPS). From the results of the study, it was found that household waste was not managed properly, most of the waste management carried out by households was by burning. Garbage collectors never take garbage into people's homes. As many as $73 \%$ of respondents do not have private latrines and $47 \%$ of respondents do not have waste water management facilities (SPAL) and 100\% of respondents carry out hygienic and sanitary behavior by washing hands with soap.
\end{abstract}

Keywords : Environmental Health Risks; Environmental Sanitation; Hygiene. 


\section{PENDAHULUAN}

Penilaian Risiko Kesehatan Lingkungan (Environmental Health Risk Assessment / EHRA) adalah sebuah studi partisipatif di kabupaten/kota untuk memahami kondisi fasilitas sanitasi dan higinitas serta perilaku-perilaku masyarakat pada skala rumah tangga. Data yang dihasilkan dapat dimanfaatkan untuk pengembangan program sanitasi termasuk advokasi di tingkat kabupaten/kota sampai dengan tingkat desa/kelurahan. Panduan pelaksanaan EHRA (Environmental Health Risk Assessment) telah mengalami perkembangan dari sebelumnya. Panduan praktis EHRA tahun 2014 tidak hanya menjangkau daerah perkotaan tetapi lebih luas ke daerah pemukiman pedesaan. Komponen sanitasi yang menjadi objek penelitianpun lebih luas yaitu limbah cair domestik, limbah padat/persampahan, drainase lingkungan, prilaku hieginis dan sanitasi termasuk Praktik Cuci Tangan Pakai Sabun (CPTS) yang diarahkan pada 5 pilar Sanitasi Total Berbasis Masyarakat (STBM).

Menurut Entjang (2000), hygiene dan sanitasi lingkungan adalah pengawasan lingkungan fisik, biologi, sosial, dan ekonomi yang mempengaruhi kesehatan manusia, dimana lingkungan yang berguna ditingkatkan dan diperbanyak sedangkan yang merugikan diperbaiki atau dihilangkan. Usaha dalam hygiene dan sanitasi lingkungan di Indonesia terutama meliputi : (1) Menyediakan air rumah tangga yang baik, cukup kualitas maupun kwantitasnya; (2) Mengatur pembuangan kotoran, sampah dan air limbah; (3) Mendirikan rumah-rumah sehat, menambah jumlah rumah agar rumah-rumah tersebut menjadi pusat kesenangan rumah tangga yang sehat; (4) Pembasmian binatang-binatang penyebar penyakit seperti : lalat, nyamuk.

Istilah hygiene dan sanitasi mempunyai tujuan yang sama, yaitu mengusahakan cara hidup sehat sehingga terhindar dari penyakit, tetapi dalam penerapannya mempunyai arti yang sedikit berbeda. Usaha sanitasi lebih menitik beratkan pada faktor lingkungan hidup manusia, sementara hygiene lebih menitik beratkan pada usaha-usaha kebersihan perorangan (Kusnoputranto, 2000).

Penyebaran penduduk Kabupaten Ogan Komering Ulu di 12 Kecamatan tidaklah merata, hal ini disebabkan karena sebagian besar penduduk lebih memilih tinggal di kecamatan yang potensial secara ekonomi dan memiliki fasilitas umum dan sosial yang lebih lengkap dibandingkan kecamatan lainnya yang masih tertinggal. Tiga Kecamatan yang memiliki jumlah penduduk terbesar di Kabupaten Ogan Komering Ulu adalah Kecamatan Baturaja Timur sebesar yaitu 109.901 jiwa, Kecamatan Peninjauan dengan penduduk sebesar 51.538 jiwa dan terakhir adalah Kecamatan Baturaja Barat berjumlah 39.997 jiwa (BPS OKU, 2019). Penduduk sebagai objek sekaligus subjek utama dalam pembangunan yang selalu menjadi perhatian bagi pemerintah baik pemerintah pusat maupun daerah, karena pertumbuhan penduduk yang terlampau tinggi akan menjadi beban bagi suatu daerah, seperti perumahan, sandang, pangan, pendidikan dan sarana penunjang lainnya. Tetapi sebaliknya penduduk yang tinggi justru diharapkan berguna untuk mempercepat pembangunan.

Analisis Resiko Lingkungan merupakan kegiatan memperkirakan kemungkinan munculnya suatu resiko dari suatu kegiatan dan menentukan dampak dari 
kegiatan/peristiwa tersebut. Dalam studi ini, analisis digunakan metode kualitatif dan metode semi kuantitatif (Idris 2003)

Analisis resiko kesehatan lingkungan perlu dilakukan pada lingkungan yang mulai mengalami pencemaran akibat aktifitas manusia. Populasi manusia yang berada pada lingkungan tercemar akan menerima resiko tercemar senyawa kimia ke dalam tubuhnya, sehingga dapat menyebabkan gangguan kesehatan pada tubuh. Untuk mengkaji berapa besar potensi bahaya dari senyawa kimia pencemar, maka perlu dilakukan analisis resiko kesehatan lingkungan (Alfiah \& Yuliawati 2018)

Berdasarkan Data EHRA (Environmental Health Risk Assessment) tahun 2018, Desa Batu Putih Kecamatan Baturaja Barat tergolong desa yang memiliki resiko sangat tinggi dalam hal kesehatan lingkungan. Yang dimaksud dengan desa beresiko sangat tinggi adalah kelurahan/desa yang dianggap memiliki resiko kesehatan lingkungan yang tinggi karena buruknya kondisi sanitasi wilayah tersebut. Berdasarkan informasi yang tersedia, kelurahan/desa yang memiliki potensi resiko tinggi berpotensi besar terjadinya kasus kejadian penyakit. Tujuan pemetaan area berisiko ini adalah untuk memetakan area yang memiliki tingkat resiko sanitasi serta klasifikasi area berdasarkan tingkat resiko kesehatan lingkungan yang akan menjadi salah satu pertimbangan dalam menentukan prioritas program pembangunan dan pengembangan sanitasi.

Berdasarkan data tersebut, Desa Batu Putih merupakan desa prioritas yang harus ditangani. Permasalahan dalam penelitian ini adalah bagaimana kualitas kesehatan lingkungan serta prilaku masyarakat di Desa Batu Putih Kecamatan Baturaja Barat. Penilaian Resiko Kesehatan lingkungan (Environmental Health Risk Assessment / EHRA) yang dilakukan di Desa Batu Putih berdasarkan panduan praktis pelaksanaan EHRA tahun 2014 yang berbeda dari panduan sebelumnya meliputi kegiatan pengelolaan sampah rumah tangga, pembuangan air limbah, drainase lingkungan, pengelolaan air minum, masak, mencuci yang aman dan hieginis, pengolahan, penyimpanan dan penanganan air yang baik dan aman serta prilaku hieginis dan sanitasi. Tujuan dari penelitian ini adalah untuk mengetahui kualitas kesehatan lingkungan dan perilaku masyarakat yang terjadi di Desa Batu Putih Kecamatan Baturaja Barat Kabupaten Ogan Komering Ulu dengan menggunakan panduan praktis EHRA (Environmental Health Risk Assessment) tahun 2014

\section{METODE PENELITIAN}

Metode yang dilakukan pada penelitian ini adalah metode survey atau pengamatan langsung di lapangan. Data yang diperlukan adalah data primer dan sekunder. Data perimer diperoleh dengan melakukan penyebaran kuisioner EHRA kepada masyarakat dan wawancara secara mendalam (depth interview). Adapun data kuisioner yang dibutuhkan adalah mengenai pengelolaan sampah rumah tangga, pembuangan air kotor/limbah, drainase lingkungan, pengelolaan air minum, masak dan mencuci yang aman dan hieginis, pengolahan, penyimpanan dan penanganan air yang baik dan aman serta prilaku hieginis dan sanitasi dari responden di lokasi penelitian. Data sekunder diperoleh dari BPS Kabupaten OKU, Dinas Kesehatan Kabupaten OKU dan instansi yang terkait dengan penelitian. Metoda penentuan target area survey dilakukan secara geografi dan demografi 
melalui proses yang dinamakan klastering. Hasil klastering ini juga sekaligus bisa digunakan sebagai indikasi awal lingkungan berisiko. Proses pengambilan sampel dilakukan secara random sehingga memenuhi kaidah "Probability Sampling" dimana semua anggota populasi memiliki peluang yang sama untuk menjadi sampel. Sementara metoda sampling yang digunakan adalah "Cluster Random Sampling". Teknik ini sangat cocok digunakan mengingat area sumber data yang akan diteliti sangat luas. Pengambilan sampel didasarkan pada daerah populasi yang telah ditetapkan. Jumlah populasi adalah sebesar 729 kepala keluarga (KK) dan jumlah sampel yang akan diteliti sebanyak 258 kepala keluarga. Pengolahan data dan analisis data dilakukan secara deskriptif dengan menggunakan tabel dan grafik.

\section{HASIL DAN PEMBAHASAN}

\section{Informasi Responden}

Responden yang menjadi sampel penelitian adalah masyarakat yang tinggal di Desa Batu Putih RT. 01 dan RT. 02. Responden adalah ibu rumah tangga atau anak perempuan yang telah menikah, yang ditampilkan dalam tabel berikut :

Tabel 1. Informasi Responden

\begin{tabular}{|c|c|c|c|}
\hline \multirow{2}{*}{\multicolumn{2}{|c|}{ Keterangan }} & \multicolumn{2}{|c|}{ Data } \\
\hline & & Jumlah & Persentase \\
\hline \multirow{6}{*}{ Kelompok Umur } & $\leq 25$ tahun & 35 & $13,60 \%$ \\
\hline & $26-30$ tahun & 58 & $22,50 \%$ \\
\hline & $31-35$ tahun & 45 & $17,40 \%$ \\
\hline & $36-40$ tahun & 63 & $24,40 \%$ \\
\hline & $41-45$ tahun & 33 & $12,80 \%$ \\
\hline & $>45$ tahun & 24 & $9,30 \%$ \\
\hline \multirow{6}{*}{ Pendidikan Terakhir } & Tidak Sekolah Formal & 10 & $3,90 \%$ \\
\hline & SD & 21 & $8,10 \%$ \\
\hline & SMP & 78 & $20,10 \%$ \\
\hline & SMA & 68 & $26,40 \%$ \\
\hline & SMK/Kejuruan & 54 & $20,90 \%$ \\
\hline & Universitas/Akademik & 48 & $18,60 \%$ \\
\hline \multirow{2}{*}{ Jumlah Anak } & Laki-laki & 53 & $54,10 \%$ \\
\hline & Perempuan & 35 & $45,90 \%$ \\
\hline \multirow{7}{*}{$\begin{array}{l}\text { Status Kepemilikan } \\
\text { tanah/lahan }\end{array}$} & Milik Sendiri & 15 & $53,10 \%$ \\
\hline & Rumah Dinas & 0 & 0 \\
\hline & Berbagi dengan keluarga lain & 0 & 0 \\
\hline & Sewa & 4 & $14,30 \%$ \\
\hline & Kontrak & 4 & $14,70 \%$ \\
\hline & Milik orangtua/anak/saudara & 2 & $17,80 \%$ \\
\hline & Lainnya & 0 & 0 \\
\hline \multirow{2}{*}{$\begin{array}{l}\text { Menerima Surat } \\
\text { Keterangan Tidak Mampu } \\
\text { (SKTM) }\end{array}$} & $\mathrm{Ya}$ & 11 & $67 \%$ \\
\hline & Tidak & 14 & $32,90 \%$ \\
\hline \multirow{2}{*}{ Menerima Surat Jamkesda } & $\mathrm{Ya}$ & 11 & $59,70 \%$ \\
\hline & Tidak & 14 & $40,31 \%$ \\
\hline
\end{tabular}


Persentase umur responden terbesar adalah berusia 36-40 tahun yaitu sebesar 24\% Hal ini menunjukkan bahwa usia responden sudah cukup untuk melakukan berbagai kegiatan rumah tangga dan melakukan kegiatan sanitasi lingkungan. Persentase pendidikan responden yang terbanyak adalah tamat SMA yaitu sebesar $26,4 \%$ dan banyak memiliki anak laki-laki dibanding perempuan yaitu sebesar 54,10 \% anak laki-laki dan $45,90 \%$ untuk anak perempuan dapat dilihat pada gambar berikut :

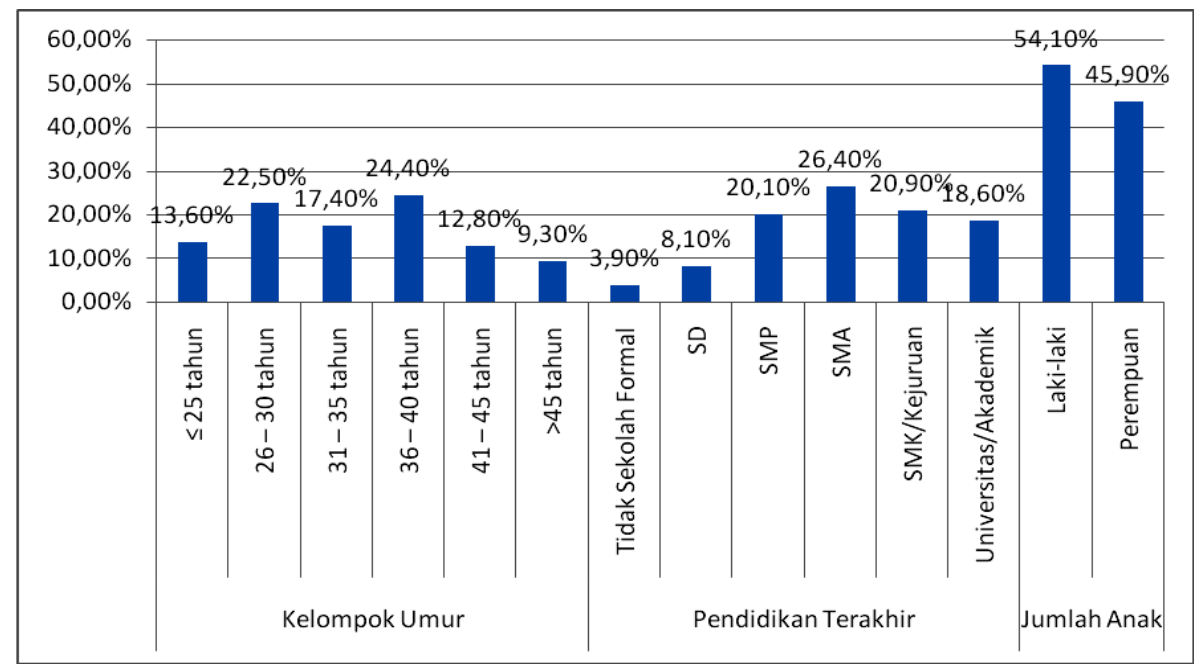

Gambar 1. Data Kelompok Umur, Pendidikan Terakhir dan Jumlah Anak Responden

Status kepemilikan tanah dan lahan responden sebagian besar adalah milik sendiri yaitu 53,10\%, 14,30\% sewa, 14,70\% kontrak, dan 17,80\% adalah milik orangtua / anak / saudara (gambar 2). Hal ini menunjukkan bahwa rumah yang yang dimiliki responden adalah rumah sendiri yang harus dijaga kebersihan lingkungan dan sanitasinya.

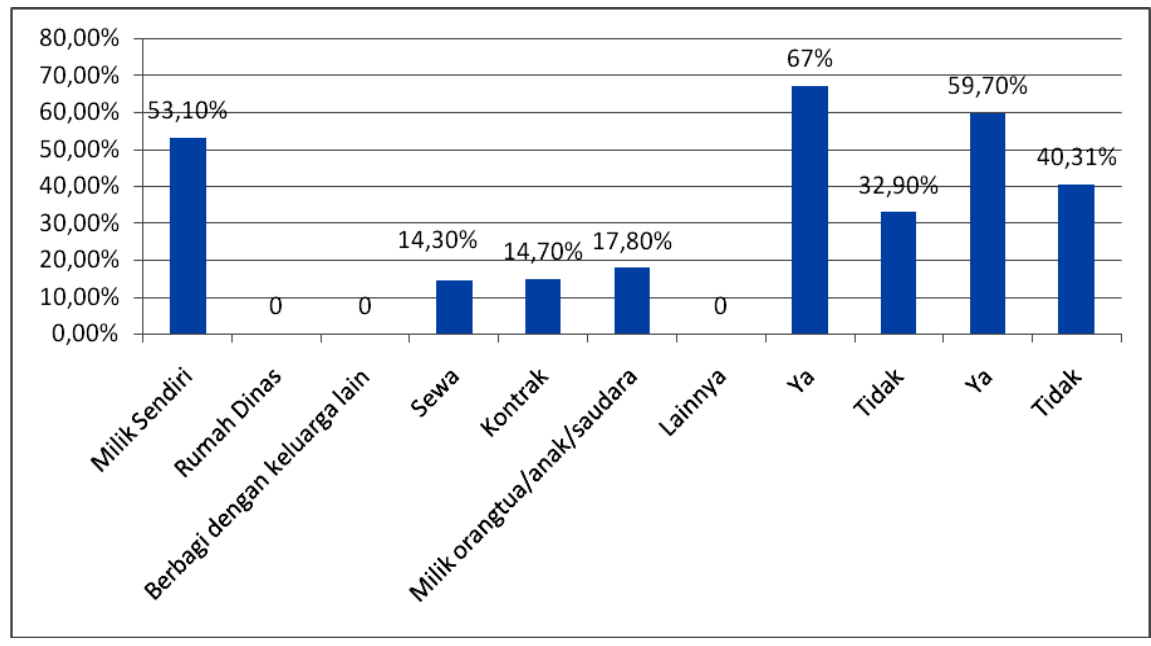

Gambar 2. Kepemilikan Tanah dan Lahan

Bantuan dari pemerintah yang diterima masyarakat berupa Surat Keterangan Tidak Mampu (SKTM) sebesar 67\% dan Surat Jaminan Kesehatan Daerah (Jamkesda) 59,7\% (gambar 3). Bantuan pemerintah ini diberikan kepada masyarakat yang tidak mampu untuk bantuan biaya hidup, pendidikan dan kesehatan. 


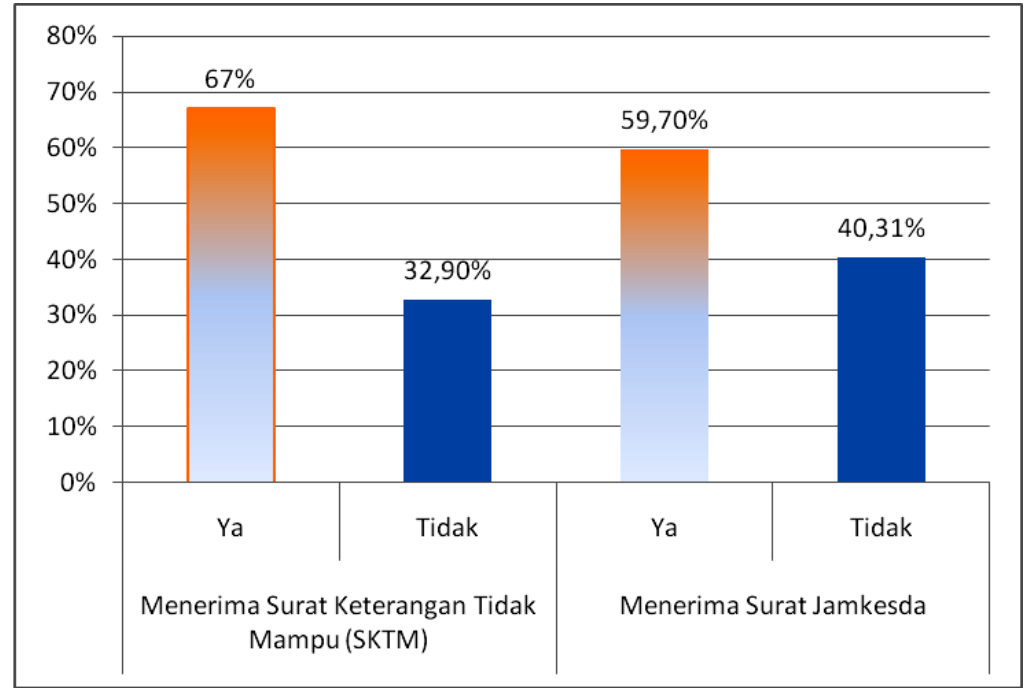

Gambar 3. Bantuan dari Pemerintah

\section{Pengelolaan Sampah Rumah Tangga}

Sampah merupakan sisa-sisa bahan yang dibuang karena sudah tidak ada manfaatnya. Bila pengelolaan sampah baik maka masyarakat akan terhindar dari penyakit dan kesehatan diri dan lingkungan menjadi terjaga. Di lokasi penelitian, kondisi sampah banyak yang berserakan disekitar rumah dan kondisinya sudah menyumbat saluran drainase. Sampah rumah tangga yang tidak dikelola dengan baik dapat menimbulkan beberapa risiko kesehatan masyarakat dan lingkungan, termasuk pencemaran air tanah, logam berat pencemaran di dalam tanah, serta produksi emisi gas rumah kaca dan volatil senyawa organik (VOC) (Sari \& Lucyana 2021). Sebagian besar pengelolaan sampah yang dilakukan oleh rumah tangga adalah dengan cara dibakar. Petugas pengangkut sampah tidak pernah melakukan pengambilan sampah ke rumah-rumah penduduk

Keadaan lingkungan di lokasi penelitian sangatlah kotor. Sampah menumpuk yang banyak dihinggapi lalat cukup banyak yaitu sebanyak 41\%. Selain lalat kondisi lingkungan juga dipenuhi oleh nyamuk yang sangat mengganggu yaitu sebesar $56 \%$. Kondisi sampah yang berserakan di lokasi penelitian sebagian besar dibakar sendiri oleh masyarakat yaitu sebesar 54\%, dibuang ke lahan kosong sebesar $24 \%$ dan ada juga yang membuangnya ke sungai sebesar $14 \%$. Sebagian besar masyarakat di lokasi penelitian tidak melakukan pemilahan sampah yaitu sebesar 73\%. Sampah yang terdapat di masyarakat dicampur menjadi satu tanpa dilakukan pemilahan lagi dan petugas pengangkut sampah tidak pernah melakukan pengangkutan sampah dari rumah masyarakat dapat dilihat pada gambar 4 dan 5 .

Kebiasaan membuang sampah sembarangan adalah bukti bahwa masih rendahnya kepedulian serta kesadaran masyarakat terhadap permasalahan kesehatan diri dan lingkungan. TPS di wilayah yang kurang memadai menyebabkan warga kesulitan dalam membuang sampah. Akibatnya sampah dibiarkan menumpuk. Sebagian kecil warga hanya mengandalkan TPS di dekat Pasar Tempel yang kapasitasnya kecil. Akses menuju TPS yang jauh juga menyebabkan warga tidak mau membuang sampah di TPS. 


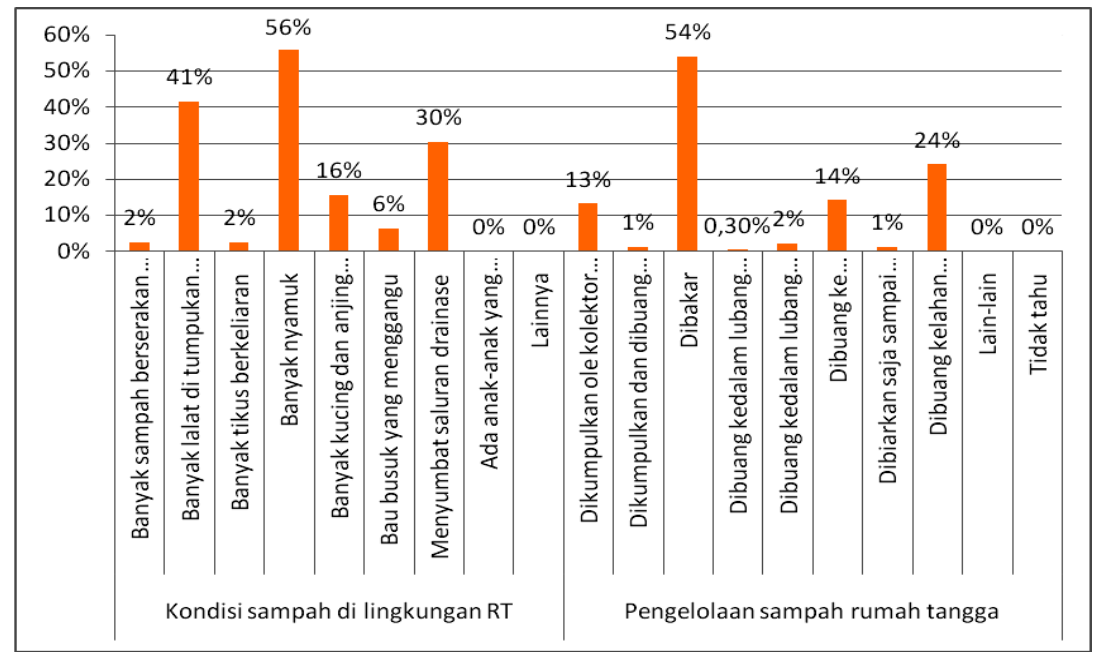

Gambar 4. Kondisi dan Pengelolaan Sampah Rumah Tangga

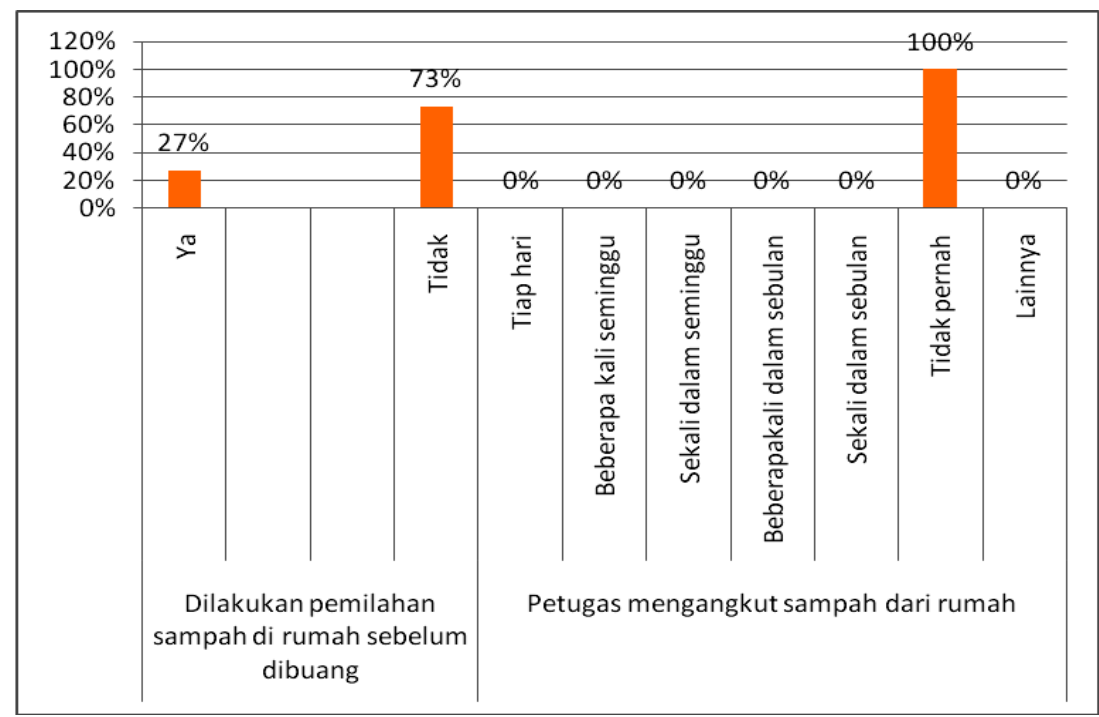

Gambar 5. Pemilahan dan Pengangkutan Sampah

\section{Pembuangan Air Kotor/Limbah Tinja Manusia Dan Lumpur Tinja}

Di lokasi penelitian, prasana pembuangan air besar belum baik, hanya $27 \%$ responden memiliki jamban pribadi dan sebesar 51\% menggunakan WC umum. Walaupun tempat tinggal responden di pinggiran Sungai Ogan, namun responden yang buang air besar ke sungai hanya $21 \%$ (gambar 6). Jenis jamban yang responden miliki adalah kloset leher angsa dan tempat pembuangan air tinjanya adalah septitank yaitu sebesar 27\% (gambar 7). Namun septitank milik responden ini tidak terpelihara dengan baik dan tidak pernah dilakukan pengurasan septitank. Umur tangki septik milik responden sebagian besar berumur 1-5 tahun yaitu sebesar 12\% dan 75\% tidak mengetahui umur tangki septiknya (gambar 8). Responden pun tidak memiliki sarana pembuangan air limbah (SPAL). Air bekas kegiatan rumah tangga, mandi, memasak, mencuci dan lain-lain langsung dibuang ke tanah. Walaupun sebagian besar responden tidak memiliki saluran drainase namun demikian pemukiman penduduk jarang sekali terkena banjir. Pemukiman respoden yang berada di pinggir sungai hanya mengalami banjir satu kali dalam setahun, tetapi banjir tidak sampai memasuki rumah penduduk. 


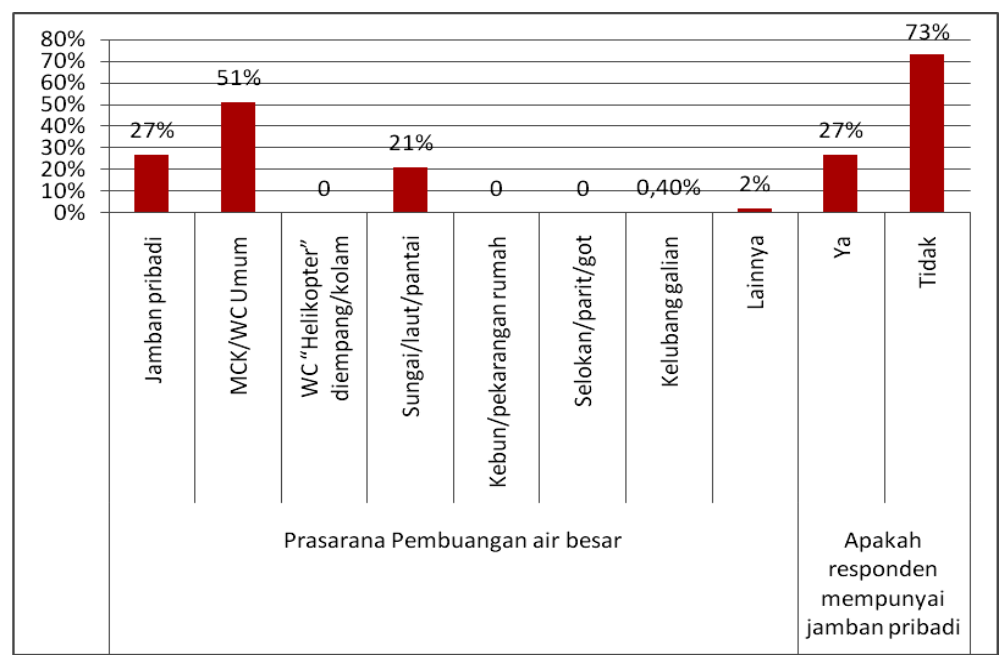

Gambar 6. Prasarana Pembuangan Air Besar

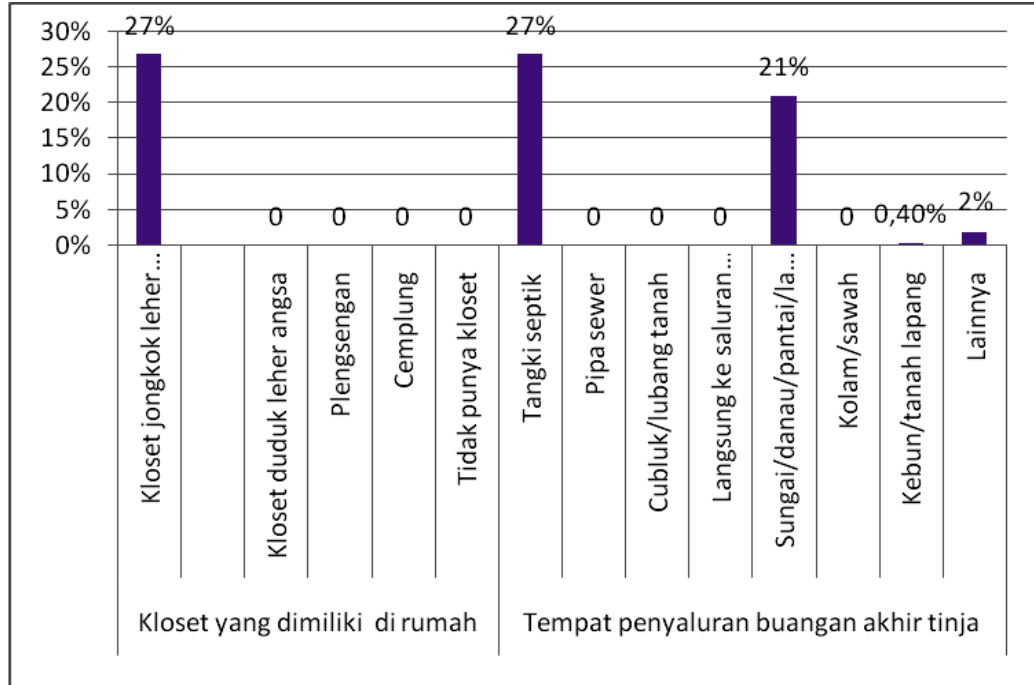

Gambar 7. Tempat Penyaluran Buangan Air

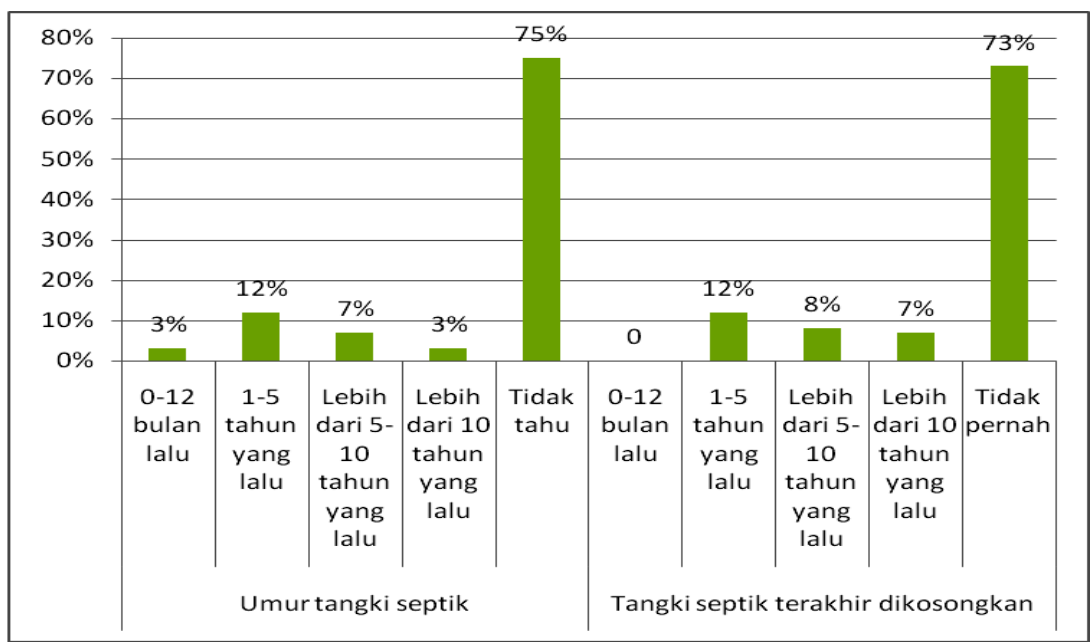

Gambar 8. Umur Tangki Septik 


\section{Drainase Lingkungan/Selokan Sekitar Rumah dan Banjir}

Kondisi drainase dan pembuangan air limbah di lokasi penelitian cukup baik, hanya 47\% responden tidak memiliki selokan atau drainase disekitar rumah sebesar 55\% memiliki drainase yang baik. Drainase lingkungan dan sarana pembuangan air limbah (SPAL) (gambar 9). Responden langsung membuang air limbah rumah tangga ke halaman rumah sehingga air langsung meresap kedalam tanah. Keadaan ini menyebabkan tanah menjadi tidak subur karena kondisi tanah telah tercemar oleh limbah rumah tangga.

Di Desa Batu Putih, banjir terjadi secara rutin hanya pada daerah tertentu saja. Daerah yang terkena banjir hanya 28\% (gambar 10) dan banjir yang terjadi di lokasi penelitian tidak sampai masuk kedalam rumah dan tidak terjadi secara rutin tiap tahunnya. Banjir yang terjadi dilokasi dikarenakan drainase yang tidak tersedia dan walaupun sudah tersedia keadaannya tersumbat oleh sampah sehingga membuat air tergenang dan rentan terjadi banjir.

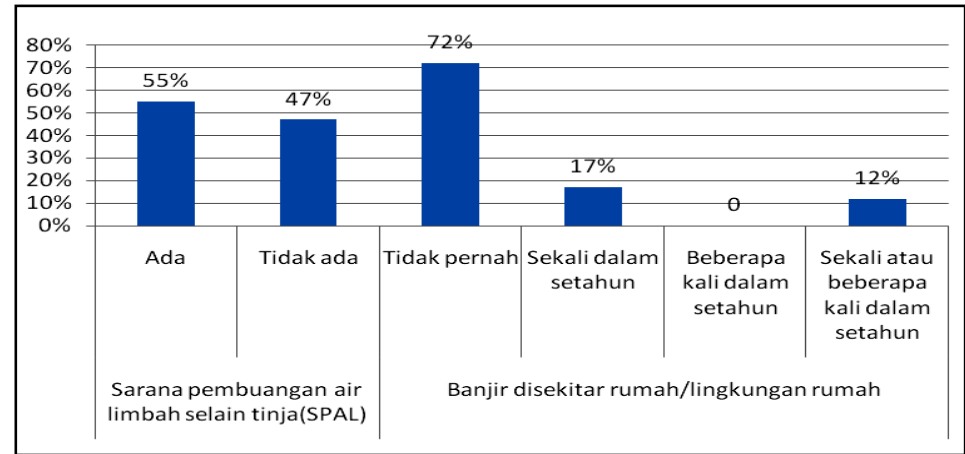

Gambar 9. Sarana Pembuangan Air Limbah (SPAL)

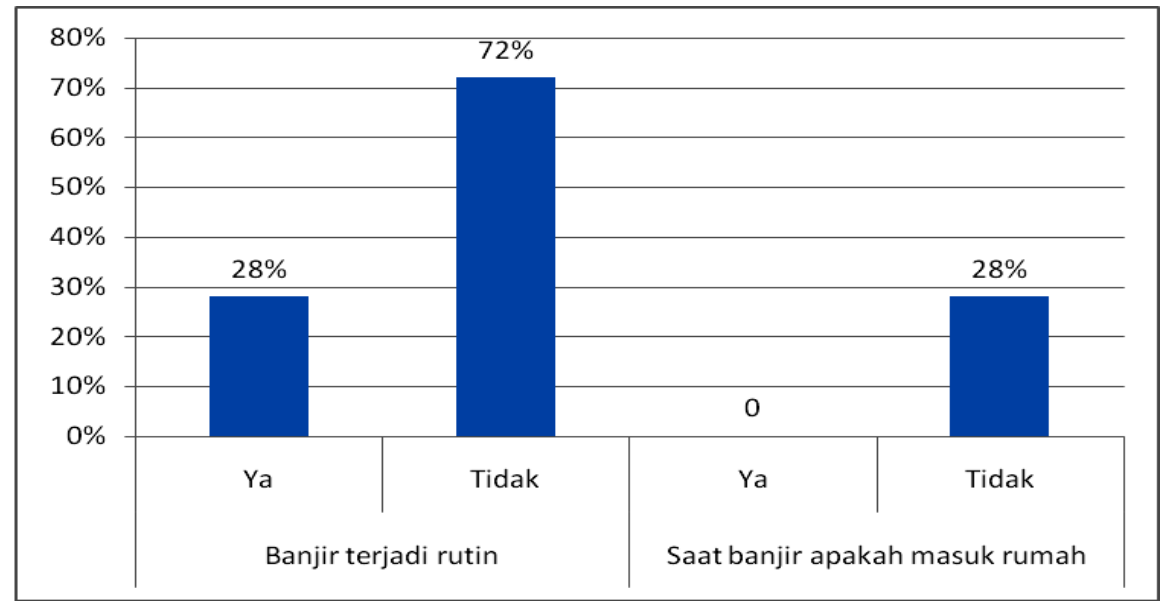

Gambar 10. Keadaan Banjir di Lokasi Penelitian

\section{Pengolahan Air Minum, Masak,Mencuci Dan Gosok Gigi Yang Aman Dan Hiegiene}

Kebutuhan air minum, masak, mencuci dan gosok gigi dari responden didapatkan dari air sumur dan air isi ulang yaitu sebesar $48 \%$ dan bahkan ada yang menggunakan air sungai sebesar $32 \%$. Untuk masak, sebagian besar responden memanfaatkan air sumur yaitu sebesar 52\% (gambar 11). Kebutuhan air minum dan memasak memerlukan kualitas air yang baik dari segi kualitas fisik dan kimia air. Kondisi air sumur di lokasi penelitian tidak terkendala kekeringan. Masyarakat dapat menggunakan air sumur dengan kualitas 
air yang baik dan berlimpah. Namun masih saja ada masyakat yang menggunakan air sungai untuk kebutuhan minum. Kondisi air sungai yang buruk sangat berbahaya bila digunakan untuk kebutuhan air minum.

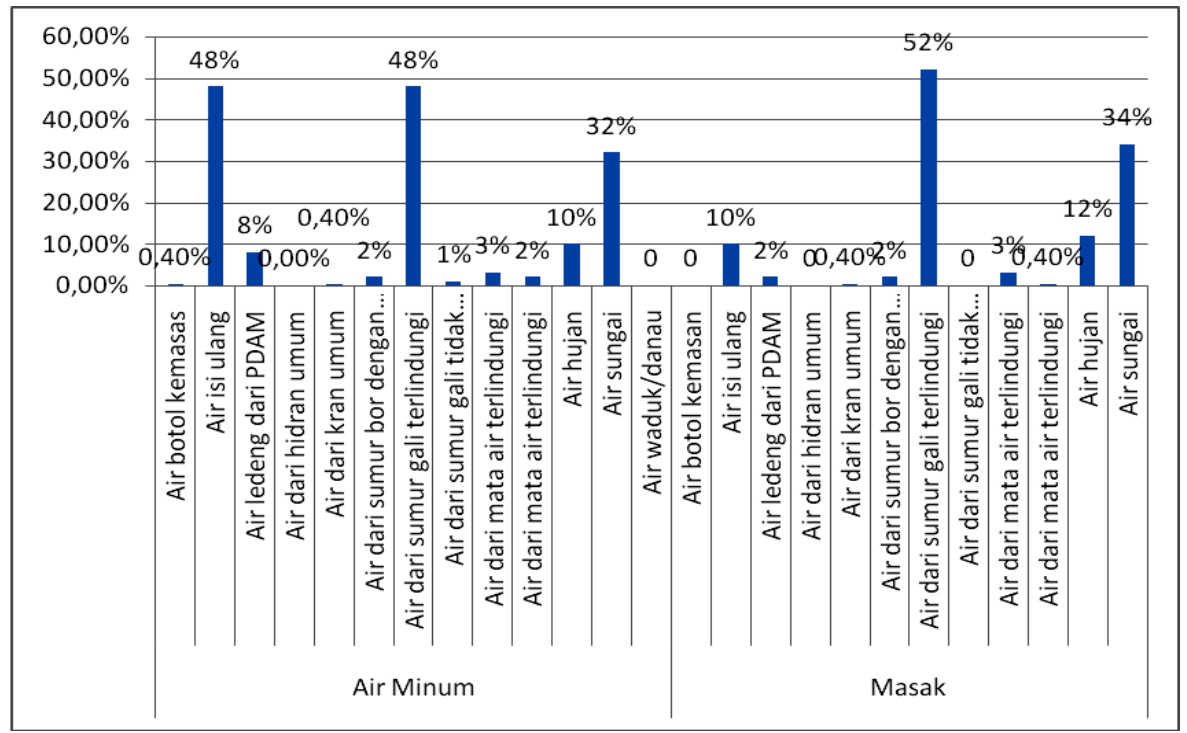

Gambar 11. Kebutuhan Air untuk Minum dan Masak

Sementara untuk cuci piring dan gelas, serta untuk gosok gigi sebagian besar masyarakat memanfaatkan air sungai untuk kebutuhan tersebut yaitu sebesar $48 \%$ (gambar 12). Masyarakat banyak memanfaatkan air sungai untuk kebutuhan mencuci pakaian, piring dan peralatan rumah tangga lainnya dan masih ada masyarakat yang buang air besar di sungai. Masyarakat di lokasi penelitian sebesar $73 \%$ tidak pernah kesulitan untuk mendapatkan air. Masyarakat memanfaatkan air Sungai Ogan untuk semua kebutuhan sehari-hari dan jarang sekali air Sungai Ogan mengalami kekeringan. Meskipun demikian masyarakat tidak merasa puas dengan kualitas air Sungai Ogan (gambar 13). Kualitas air sungai sering keruh, hal ini terjadi karena limpasan lumpur dan pasir yang terbawa dari hulu sungai, dan keadaan ini sering sekali terjadi. Selain itu kualitas air sungai yang tidak baik disebabkan banyak masyarakat yang membuang sampah di sungai sehingga kondisi air sungai menjadi tercemar.

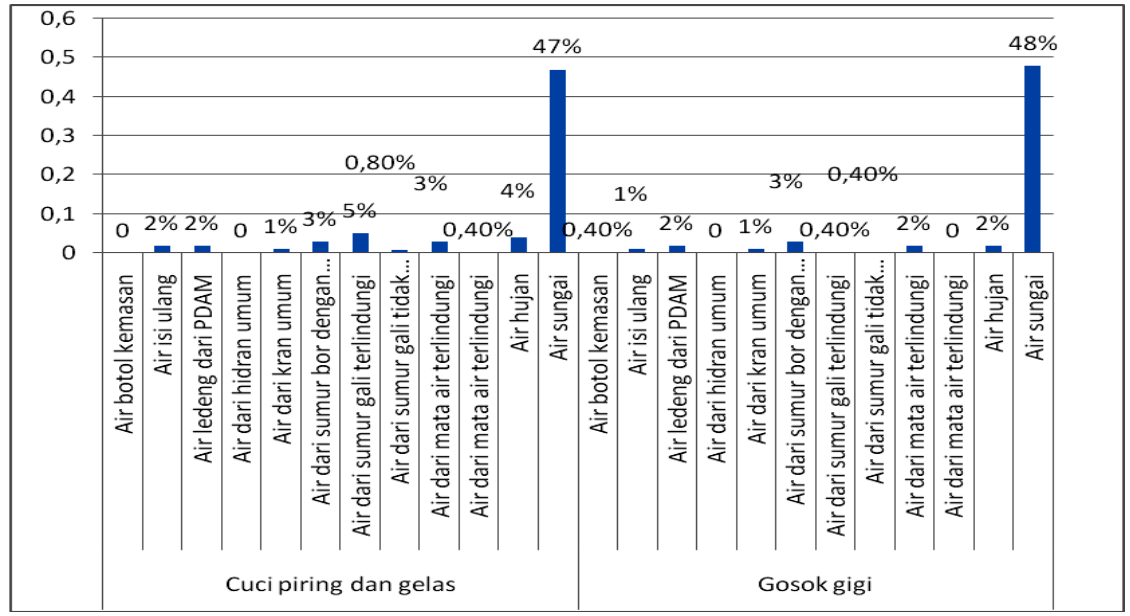

Gambar 12. Kebutuhan air untuk Cuci Piring dan Gosok Gigi 


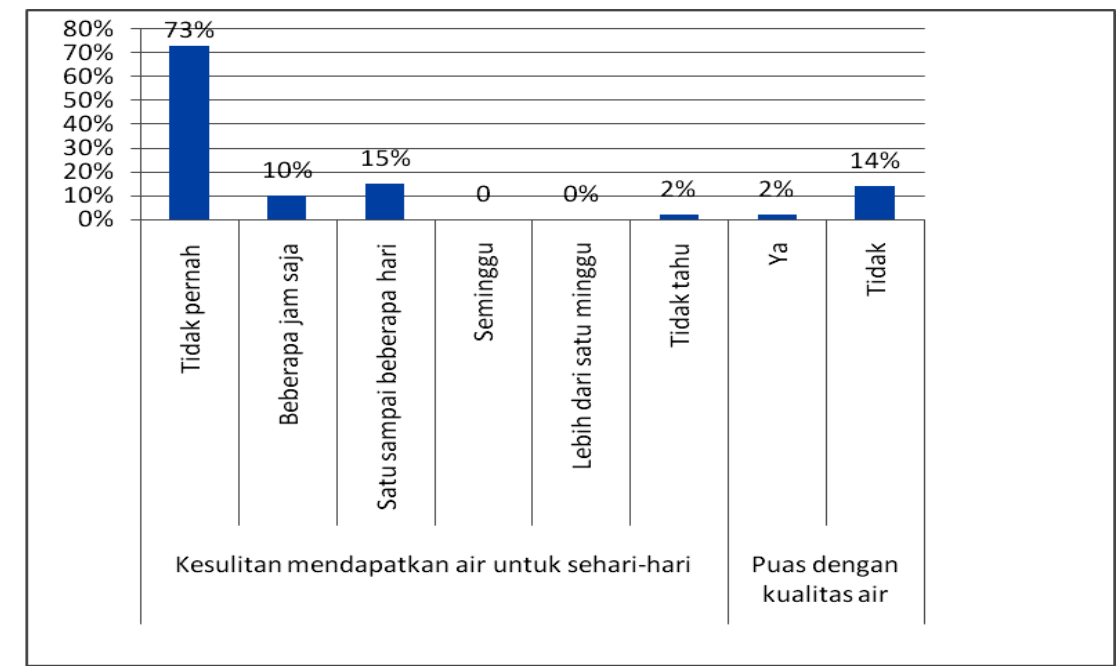

Gambar 13. Kepuasan Kualitas Air

\section{Pengolahan, Penyimpanan Dan Penanganan Air Yang Baik Dan Aman}

Kesadaran responden dalam mengolah air sebelum digunakan untuk minum dan memasak sangatlah baik. Sebesar $100 \%$ responden telah melakukan pengolahan air dulu sebelum air tersebut digunakan untuk minum dan memasak (gambar 14). Responden melakukan pengolahan air dengan cara direbus. Sebanyak $61 \%$ responden menampung air dalam drum atau wadah yang tertutup. Sedangkan air yang sudah direbus responden letakkan di dalam panci yang tertutup. Cara pengambilan air yang akan direbus, responden lakukan dengan menggunakan gayung yang kering, dimana tangan tidak bersentuhan dengan airnya (gambar 15).

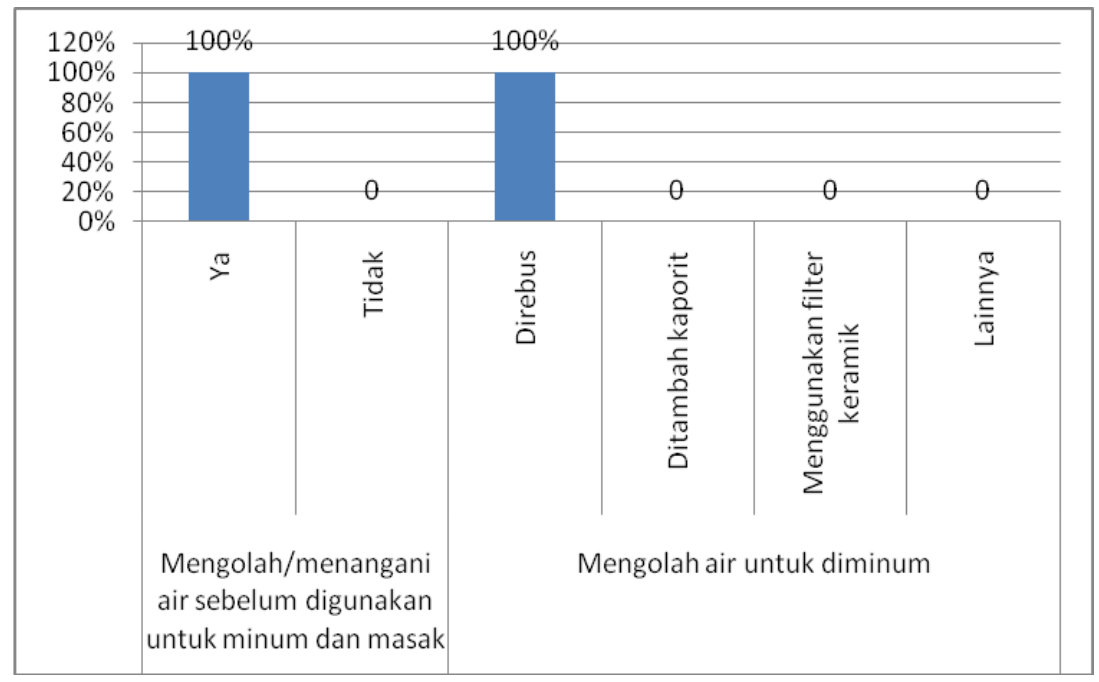

Gambar 14. Mengolah Air Untuk Diminum 


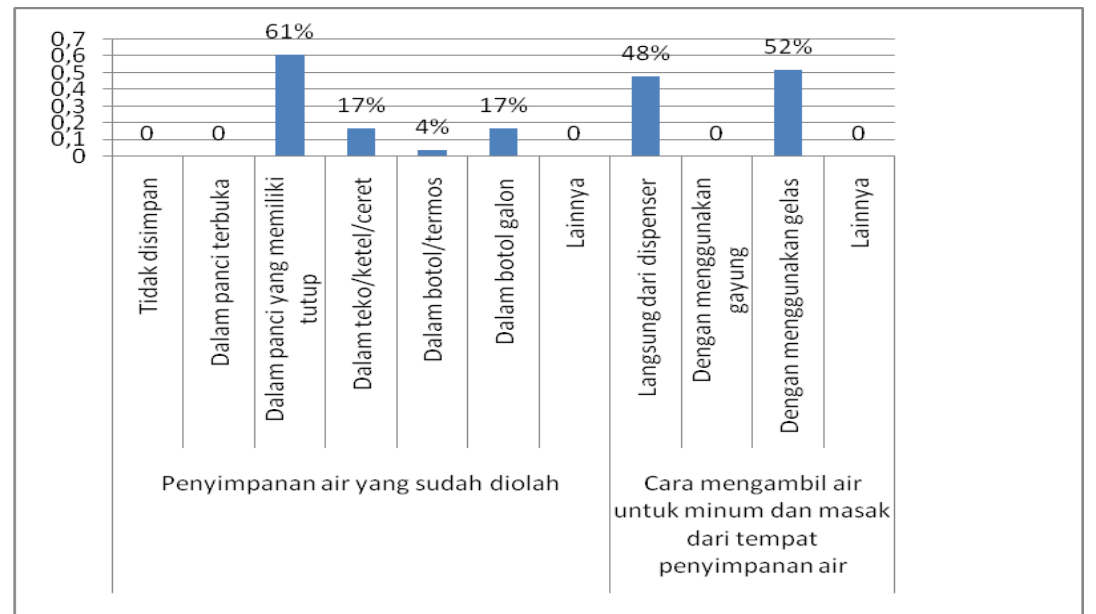

Gambar 15. Penyimpanan Air yang Sudah Diolah

\section{Perilaku Hiegiene Dan Sanitasi}

Menurut Depkes RI (2014) hiegine adalah upaya pencegahan timbulnya penyakit karena kondisi lingkungan serta membuat kondisi lingkungan sedemikian rupa sehingga kesehatan lingkungan menjadi terpelihara. Sanitasi adalah budaya hidup bersih dengan cara pencegahan manusia bersentuhan langsung dengan kotoran maupun zat berbahaya lainnya dalam upaya meningkatkan kesehatan manusia (Misrah \& Mulyadi 2020). Hygine dan sanitasi erat hubungannya dalam upaya mencegah penyakit terhadap masyarakat yang menjadi tujuan dari kesehatan masyarakat dan lingkungan (Yarmaliza \& Rinaldy 2020).

Program Cuci Tangan Pakai Sabun (CPTS) adalah salah satu program pemerintah dalam upaya mengubah prilaku higienis dan saniter melalui pendekatan pemberdayaan masyarakat yaitu pendekatan Sanitasi Total Berbasis Masyarakat. Dalam kehidupan sehari-hari $100 \%$ responden selalu menggunakan sabun dalam setiap aktifitasnya (gambar 16). Sabun digunakan responden untuk kegiatan mandi, cuci tangan sehabis melakukan aktifitas sehari-hari, mencuci piring dan gelas, mencuci pakaian dan lain-lain. Kebiasaan mencuci tangan pakai sabun $100 \%$ dilakukan responden setelah aktifitas buang air besar, sebelum makan dan setelah makan, sebelum menyiapkan makanan (gambar 17).

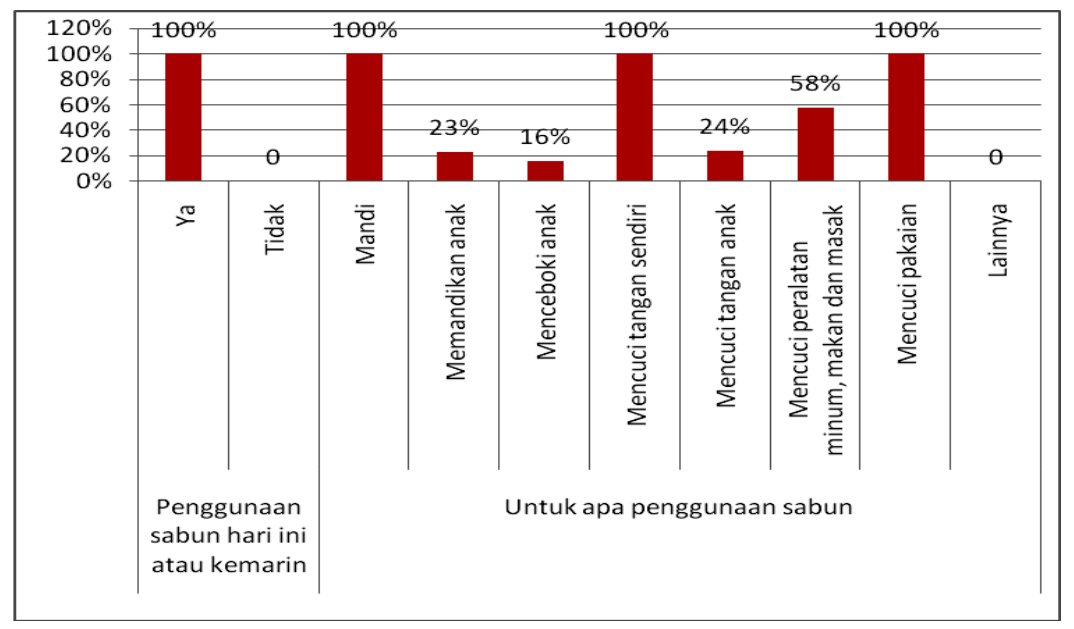

Gambar 16. Penggunaan Sabun Untuk CPTS 


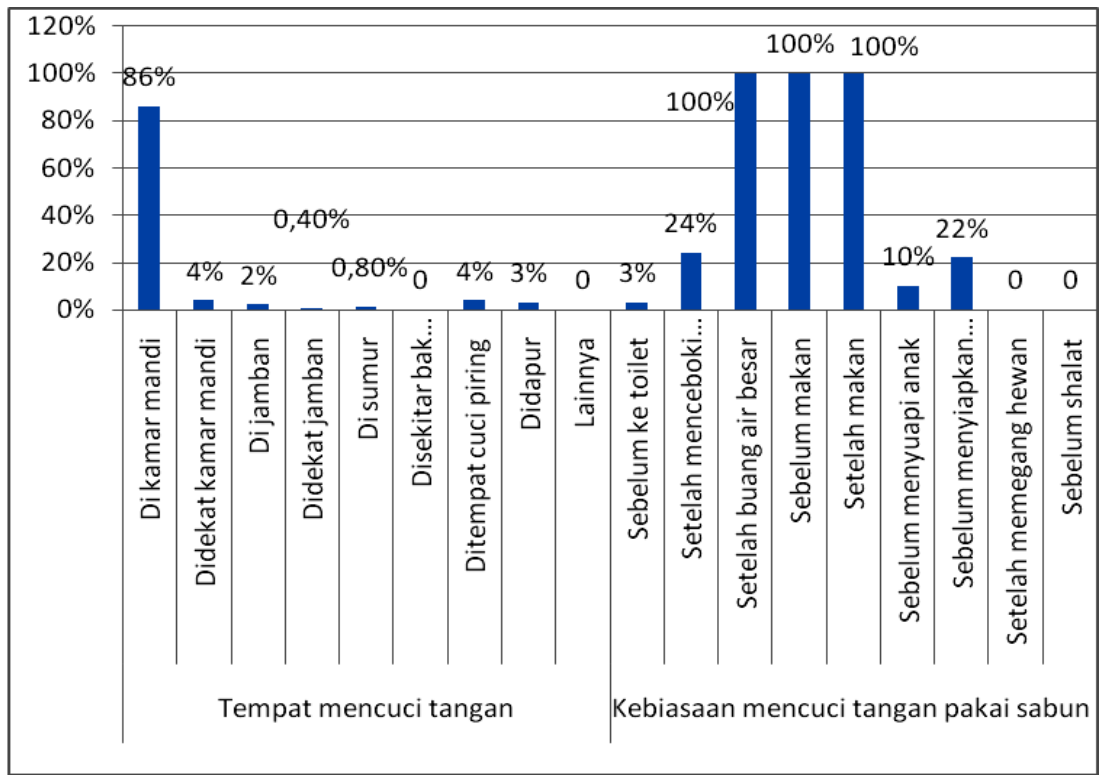

Gambar 17. Kebiasaan Mencucui Tangan Pakai Sabun

Penyakit diare adalah penyakit yang timbul berkenaan dengan prilaku hidup sehat yang dilakukan masyarakat sehari-hari. 96\% responden mengatakan tidak pernah terkena diare (gambar 18). Penyakit yang sering responden alami adalah batuk dan pilek yang tidak henti-henti yang dialami oleh anak-anak dan orang dewasa. Fenomena asap kendaraan dan debu yang dikeluarkan oleh PT. Semen Baturaja membuat penyakit ini sering ditemukan di lokasi penelitian.

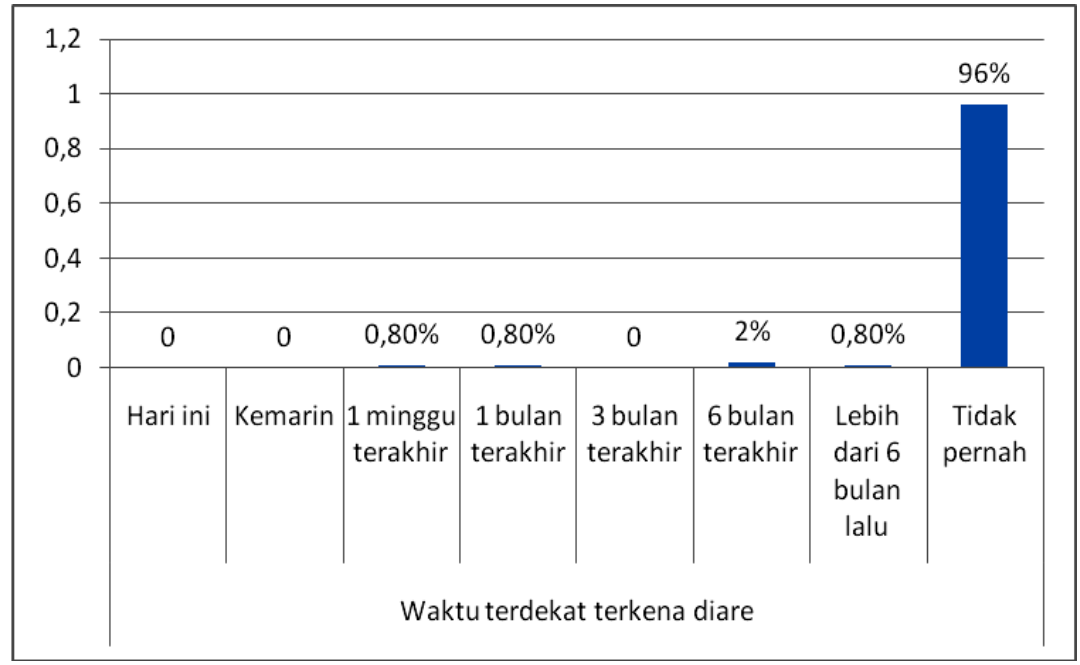

Gambar 18. Fenomena Terkena Penyakit Diare

\section{KESIMPULAN}

Studi Penilaian Risiko Kesehatan Lingkungan (Environmental Health Risk Assessment / EHRA) adalah sebuah survey partisipatif di tingkat kabupaten/kota untuk memahami kondisi fasilitas sanitasi dan higinitas serta perilaku-perilaku masyarakat pada skala rumah tangga. Dari hasil penelitian didapatkan bahwa sampah rumah tangga tidak dikelola dengan baik, sebagian besar pengelolaan sampah yang dilakukan adalah dengan cara dibakar. Petugas pengangkut sampah tidak pernah melakukan pengambilan sampah 
ke rumah-rumah penduduk. Sebesar $73 \%$ responden tidak memiliki jamban pribadi dan 47\% responden tidak memiliki Sarana Pengelolaan Air Limbah (SPAL) dan 100\% rersponden melakukan prilaku hieginis dan sanitasi yaitu dengan melakukan Cuci Tangan Pakai Sabun (CTPS).

\section{DAFTAR PUSTAKA}

Alfiah, T., \& Yuliawati, E. (2018). Analisis Resiko Kesehatan Lingkungan Udara Ambien Terhadap Pengguna Jalan dan Masyarakat Sekitar Pada Ruas Jalan Ir. Sukarno Surabaya. INFOMATEK: Jurnal Informatika, Manajemen dan Teknologi, 20(1), 27-34.

Badan Pusat Statistik. 2019. Kabupaten Ogan Komering Ulu dalam Angka.

Departemen Kesehatan Republik Indonesia. 2014. Profil Kesehatan Indonesia. Jakarta

Entjang, 2000. Ilmu Kesehatan Masyarakat, PT Citra Adtya Bakti, Bandung.

Idris, Y.Z. 2003. Analisa Resiko Limbah Industri Tapioka di Sungai Tulang Bawang. Program Pascasarjana. Program Studi Magister Teknik Lingkungan ITS, Surabaya.

Kusnoputranto,H, 2000, Kesehatan Lingkungan. Fakultas Kesehatan Masyarakat Universitas Indonesia,Jakarta.

Laporan Studi EHRA (Environmental Health Risk Assessment). 2014. Program Percepatan Pembangunan Sanitasi Pemukiman. Pemerintah Kabupaten Langkat Provinsi Sumatera Utara.

Misrah, M., \& Mulyadi, M. (2020). Gambaran Sarana Sanitasi Dasar Di Dusun Lembang Desa Bonto Biraeng Kecamatan Kajang Kabupaten Bulukumba. Sulolipu: Media Komunikasi Sivitas Akademika dan Masyarakat, 19(2), 223-228.

Notoatmodjo S. 2003. Ilmu Kesehatan Masyarakat Prinsip-prinsip Dasar. Jakarta: PT Rineka Cipta..

Sari, E. K., \& Lucyana, L. (2021). Evaluasi Instalasi Pengolahan Air Lindi Di Tempat Pembuangan Akhir Sampah (TPAS) Simpang Kandis Kabupaten Ogan Komering Ulu. Jurnal Deformasi, 6(1), 33-41.

Yarmaliza, Y., \& Rinaldy, R. (2020). Penyuluhan Higiene dan Sanitasi Di Lingkungan Rumah Tangga. COMSEP: Jurnal Pengabdian Kepada Masyarakat, 1(1), 105-109. 